Erratum

\title{
Erratum: Moreira, J., et al., Spin-Coated Polysaccharide-Based Multilayered Freestanding Films with Adhesive and Bioactive Moieties. Molecules 2020, 25, 840
}

\author{
Joana Moreira ${ }^{1,2} \mathbb{C}^{(}$, Ana C. Vale ${ }^{1,2, * \mathbb{C}}$, Ricardo A. Pires ${ }^{1,2,3}$, Gabriela Botelho ${ }^{4} \mathbb{C}_{\text {, }}$ \\ Rui L. Reis ${ }^{1,2,3}$ and Natália M. Alves ${ }^{1,2, *}$ \\ 1 3Bs Research Group, I3Bs-Research Institute on Biomaterials, Biodegradables and Biomimetics, \\ University of Minho, Headquarters of the European Institute of Excellence on Tissue Engineering and \\ Regenerative Medicine, Avepark, Barco, 4805-017 Guimarães, Portugal; joana.lagoa@hotmail.com (J.M.); \\ rpires@i3bs.uminho.pt (R.A.P.); rgreis@i3bs.uminho.pt (R.L.R.) \\ 2 ICVS/3B's, Associate PT Government Laboratory, 4710-057 Braga/4805-017 Guimarães, Portugal \\ 3 The Discoveries Centre for Regenerative and Precision Medicine, Headquarters at University of Minho, \\ Avepark, Barco, 4805-017 Guimarães, Portugal \\ 4 Department of Chemistry, University of Minho, Campus de Gualtar, 4710-057 Braga, Portugal; \\ gbotelho@quimica.uminho.pt \\ * Correspondence: catarina.vale@i3bs.uminho.pt (A.C.V.); nalves@i3bs.uminho.pt (N.M.A.)
}

Received: 23 March 2020; Accepted: 14 May 2020; Published: 12 June 2020 updates

The authors wish to make changes to the published paper [1].

\section{UV-Vis Analysis of Catechol-Modified Polymers}

In the original manuscript, there is a mistake concerning the word "Wavenumber" in the X-coordinate in Figure 1. The corrected word is "Wavelength". The authors also wish to change $\mathrm{mg} \bullet \mathrm{mL}-1$ to $\mathrm{mg} \mathrm{mL}-1$ in the legend of Figure 1; see corrected Figure 1 below.

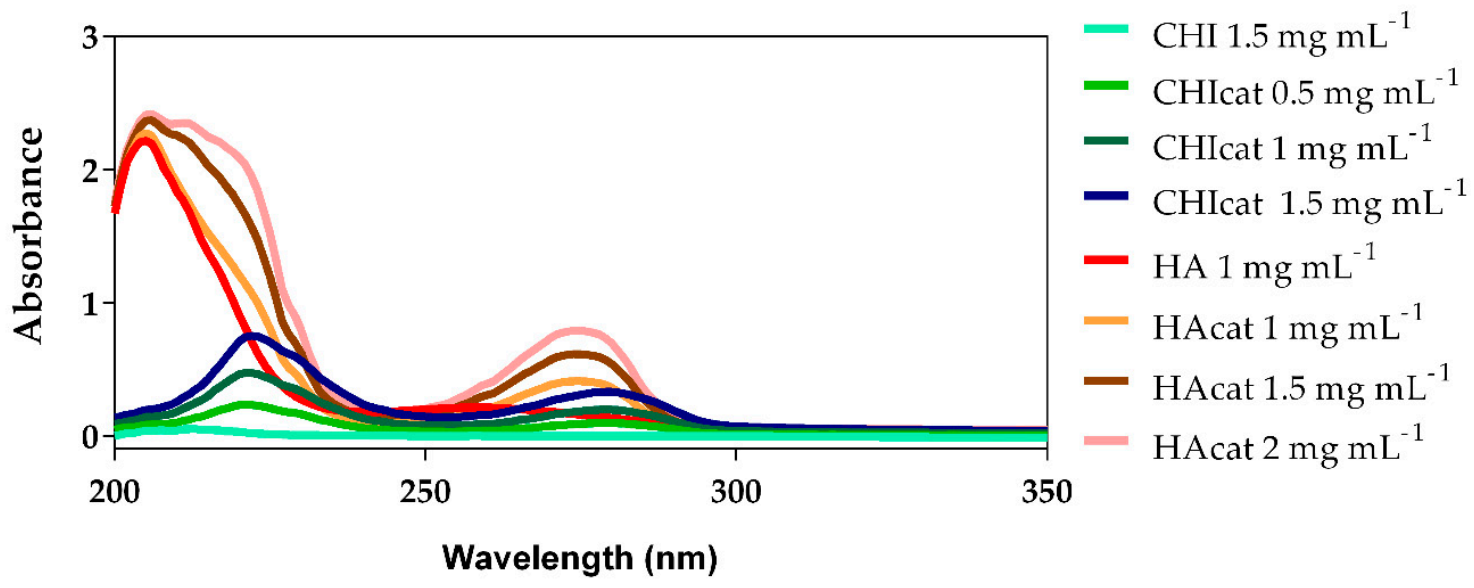

Figure 1. UV-Vis spectra of chitosan (CHI) and hyaluronic acid (HA), catechol-conjugated CHI (CHIcat) and catechol-conjugated HA (HAcat) $(\lambda=200-350 \mathrm{~nm})$

\section{Thermogravimetric Analysis (TGA)}

There is a mistake with the word "CNT" in the legend of Figure 8. The corrected word is "CTR"; see corrected Figure 8 below. 

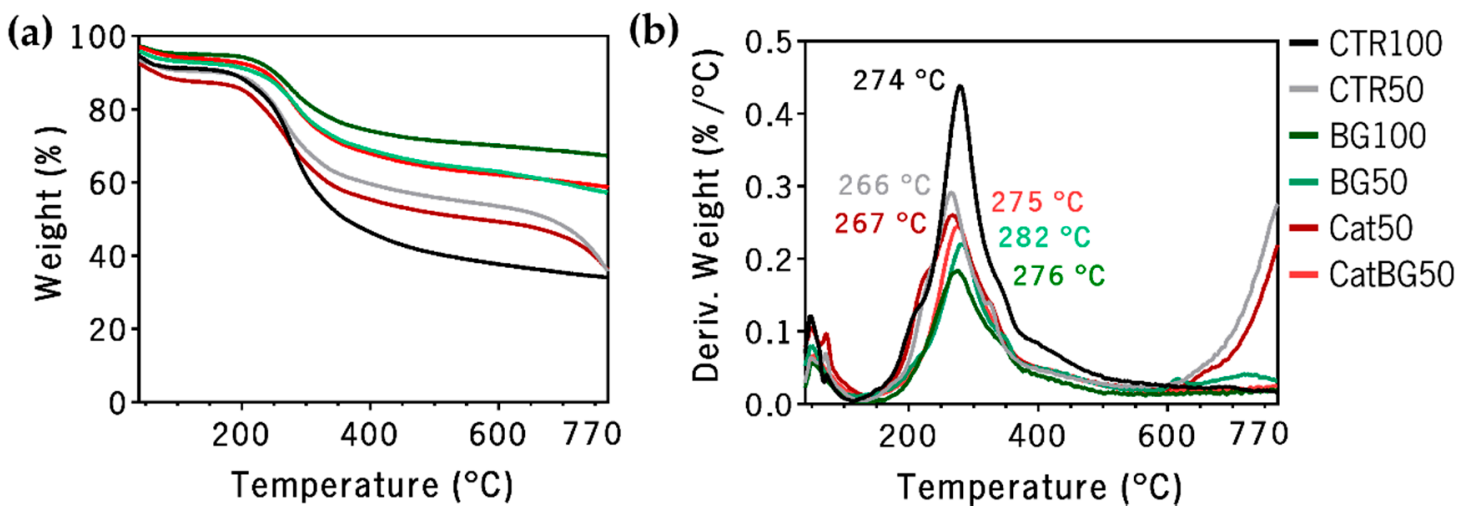

Figure 8. TGA thermograms of (a) weight loss and (b) derivative of the weight loss (DTGA) of the freestanding $\mathrm{LbL}$ films as a function of temperature.

\section{Conclusions}

The authors wish to change a sentence at the end of Section "Conclusions". The original sentence is "These bioactive LbL freestanding films that combine good adhesion with improved mechanical properties could find applications in the biomedical field, such as guided hard tissue regeneration (GTR) membranes." The corrected sentence is "These bioactive LbL freestanding films that combine good adhesion with improved mechanical properties could be an alternative strategy for guided hard tissue regeneration."

Finally, there is a mistake with the word "cross-link" in the main text. The corrected word is "crosslink".

The authors apologize for any inconvenience caused and the change does not affect the scientific results. The manuscript will be updated, and the original will remain online on the article webpage at https://www.mdpi.com/1420-3049/25/4/840.

\section{Reference}

1. Moreira, J.; Vale, A.C.; Pires, R.A.; Botelho, G.; Reis, R.L.; Alves, N.M. Spin-Coated Polysaccharide-Based Multilayered Freestanding Films with Adhesive and Bioactive Moieties. Molecules 2020, 25, 840. [CrossRef] [PubMed]

(C) 2020 by the authors. Licensee MDPI, Basel, Switzerland. This article is an open access article distributed under the terms and conditions of the Creative Commons Attribution (CC BY) license (http://creativecommons.org/licenses/by/4.0/). 